\title{
The association between maternal features and nutritional problems in children with autism spectrum disorder
}

\author{
Associação entre características maternas e \\ problemas nutricionais em crianças com
}

transtorno do espectro do autismo

\author{
Nur ATEŞ-ŞAHINKAYA ${ }^{1}$ (ID) 0000-0002-5081-8455 \\ Nilüfer ACAR-TEK² (ID) 0000-0002-8772-9608 \\ Emre ADIGÜZEL3 ID $^{0}$ 0000-0002-9041-8990
}

A B S T R A C T

\section{Objective}

In the literature, there is almost no data on the relationship between autistic children's nutritional problems and their mothers' demographic and nutritional characteristics. Therefore, this study aimed to evaluate whether there was a relationship between maternal features and nutritional problems in autistic children.

\section{Methods}

This study was conducted with the participation of 58 autistic children (6-19 years) and their mothers. Descriptive data were obtained with a general questionnaire. For the evaluation of children's nutritional status, anthropometric measurements and 24-hour dietary recall were used. Also, the Brief Autism Mealtime Behavior Inventory and ORTO-15 questionnaires were used to evaluate the meal behavior of children and orthorexia tendency of mothers, respectively.

\footnotetext{
1 Eskişehir Osmangazi University, Health Practice and Research Hospital, Dietetic Department. Eskişehir, Turkey.

2 Gazi University, Faculty of Health Sciences, Department of Nutrition and Dietetics. Ankara, Turkey.

${ }^{3}$ Karamanoğlu Mehmetbey University, Faculty of Health Sciences, Department of Nutrition and Dietetics. Yunus Emre Campus, İbrahim Öktem Street, 70100, Karaman, Turkey. Correspondence to: E. ADIGÜZEL. E-mail: <adiguzlemre@gmail.com>.

Article elaborated from dissertation by N. ATEŞ-ŞAHINKAYA, entitled "The evaluation of meal time behavior and nutritional status in children and adolescents with autism, and orthorexia tendency of their mothers". Gazi University; 2016.
}

How to cite this article

Ateş-Şahinkaya N, Acar-Tek N, Adıgüzel E. The association between maternal features and nutritional problems in children with autism spectrum disorder. Rev Nutr. 2020;33:e190217. https://doi.org/10.1590/1678-9865202033e190217 


\section{Results}

No significant correlation was found between the Brief Autism Mealtime Behavior Inventory scores in children of mothers with high and low orthorexia tendency. There were also no statistically significant differences between the children of mothers with high and low educational level in terms of Brief Autism Mealtime Behavior Inventory scores. Only the dietary vitamin B6 intake was significantly higher in the children of mothers with high educational level. Maternal age was associated with the dietary energy and protein intake, unlike, maternal orthorexia tendency was not associated with the nutritional status and meal behavior of children. The abdominal pain experience in the last one month was found to be significantly higher in the children of employed mothers than children of unemployed mothers.

\section{Conclusion}

It is thought that the maternal characteristics are not effective on meal behavior in children and also maternal age and educational status have a very limited effect on the nutritional status of children.

Keywords: Autism. Maternal educational status. Maternal nutrition. Mealtime.

\section{RE S U M O}

\section{Objetivo}

Na literatura, quase não existem dados sobre a relação entre os problemas nutricionais de crianças autistas e as características demográficas e nutricionais de suas mães. Portanto, este estudo teve como objetivo avaliar se havia relação entre características maternas e problemas nutricionais em crianças autistas.

\section{Métodos}

Este estudo foi realizado com a participação de 58 crianças autistas (6-19 anos) e suas mães. Os dados descritivos foram obtidos em questionário geral. Para a avaliação do estado nutricional das crianças, medidas antropométricas e rec24h foram utilizados. Além disso, os questionários Brief Autism Mealtime Behavior Inventory e ORTO-15 foram utilizados para avaliar o comportamento alimentar das crianças e a tendência à ortorexia das mães, respectivamente.

\section{Resultados}

Não foi encontrada correlação significativa entre os escores do Brief Autism Mealtime Behavior Inventory nos filhos de mães com alta e baixa tendência à ortorexia. Também não houve diferenças estatisticamente significativas entre os filhos de mães com nível educacional alto e baixo em termos de pontuação no Brief Autism Mealtime Behavior Inventory. Somente a ingestão alimentar de vitamina B6 foi significativamente maior nos filhos de mães com alto nível educacional. A idade materna foi associada à ingestão energética e proteica, diferentemente da tendência à ortorexia materna, não associada ao estado nutricional e ao comportamento das refeições. A experiência de dor abdominal no último mês foi significativamente maior nos filhos de mães que trabalham do que nos filhos de mães que não trabalham.

\section{Conclusão}

Acredita-se que as características maternas não influenciam o comportamento alimentar das crianças e também que a idade e o estado educacional da mãe têm um efeito muito limitado no estado nutricional das crianças.

Palavras-chave: Autismo. Nível educacional materno. Nutrição materna. Hora das refeições.

\section{NTRODUCTIO N}

Autism Spectrum Disorder (ASD) is the name of a group of neurodevelopmental disorders with a complex multifactorial etiology. ASD is characterised by persistent abnormal social interactions (e.g., obvious impairment in eye-to-eye gaze, lack of joint attention) and restricted repetitive and stereotyped patterns of behavior, interests, and activities which start in very early life [1]. ASD becomes apparent before the $24^{\text {th }}$ month of age and persists into adulthood, causing lifelong disability $[2,3]$. There are three distinct groups of ASD identified in the Diagnostic and Statistical Manual of Mental 
Disorders (DSM-IV-TR); autistic disorder, Asperger syndrome and Pervasive Developmental DisorderNot Otherwise Specified (PDD-NOS) [4]. This classification is reviewed in the new edition published in 2013 Diagnostic and Statistical Manual of Mental Disorders (DSM-5) [1]. The incidence of ASD is dramatically increasing year by year and about one child to 59 has been identified with ASD according to estimates from Centers for Disease Control and Prevention's (CDC) Autism and Developmental Disabilities Monitoring (ADDM) Network [5]. ASD is reported to occur in all racial, ethnic, and socioeconomic groups and it is almost five times more common among boys than girls [6-8].

The majority of children with ASD has been found to present comorbid nutrition problems, especially some mealtime issues [9]. Generally, these problems tended to separate to three categories: (1) food selectivity based on type and texture, (2) food refusal, and (3) disruptive mealtime behaviors. Collectively, these reports indicate that children with ASD have more nutritional problems caused by mealtime behaviors and more narrow in the foods they accept [10]. Besides all these data, it has been reported that $25 \%$ of children with ASD have at least one gastrointestinal (GI) symptom (e.g., diarrhea, constipation, abdominal pain, and GI reflux disease). This strongly suggests that the routine treatment should be accompanied by the nutritional therapy in children with ASD [11]. Parents, children's first role model, have an important influence on the dietary behavior of their children $[12,13]$. Therewithal, the employment of women increases household income, and as a result, this positively affects the nutritional status of households, especially mothers. What's more, studies indicate that there is a strong relationship between the maternal education level and children's nutritional status [14]. So, mothers' empowerment can affect children's nutritional status because of the fact that mother's diet quality is an important predictor for the child's diet quality [15].

In the studies, the effects of the economic power, educational level and health literacy of the parents on the nutritional status of the children without specific diseases were evaluated. In addition, the relationship between nutritional status of children and some maternal features such as employment, order of birth and birth interval has been studied [16-23]. The difference of our study from these studies is that it was conducted on children with ASD. In the literature, there is almost no data on the association between maternal characteristics (demographic features and nutritional status of mothers) and autism-related nutritional problems (meal behavior and nutritional status of children). This paper provides an opinion on whether there was a relationship between the maternal features and common eating disorders such as picky eating, food refusal and inadequate dietary intake in autistic children.

\section{METHO D S}

This descriptive and cross-sectional study was conducted with autistic children and adolescents (6-19 years) who were registered to special education centers in Eskişehir, Turkey, and with their mothers in January-July 2016. PASS 11, a sample size software, was used for the determination of sample size. In determining the sample size, the mean dietary energy intake reported in a study $(1938.7 \pm 426.3 \mathrm{kcal})$ evaluating the nutritional status of autistic children was based [24]. For $95 \%$ and $80 \%$ statistical power, the sample size required 71 and 44 subjects, respectively.

An invitation was sent to the families for "The informative meeting about the study" through the managers of special education centers. Clear explanations about the study design and rights of the participants were provided for the families attended the meetings. A total of 58 mothers agreed to participate in the study with a written informed consent in accordance with Declaration of Helsinki (World Medical Association). 
Descriptive and maternal characteristics (gender, age, age at diagnosis, maternal age at birth, maternal education and employment status) and GI symptoms (diarrhea and abdominal pain) of the children were obtained with a general questionnaire. Also, in some evaluations, the children were divided into two groups as school-age children (6-12 years of age) and adolescents (over 12 years), as stated by the World Health Organization (WHO) [25]. For the evaluation of nutritional status and meal behavior, the anthropometric measurements (height and body weight) and 24-hour dietary recall (24HR) were taken, and the Brief Autism Mealtime Behavior Inventory (BAMBI) was applied [26]. Also, for the evaluation of orthorexia nervosa tendency of the mothers, the ORTO-15 questionnaire was applied with face-to-face interview [27]. For the study, ethical approval was obtained from Gazi University Ethics Committee (dated January 15, 2016. Project n. 77082166-604.01.02).

Autistic children and adolescents who were diagnosed with a chronic disease or who have a special diet (i.e. gluten-free diet, casein-free diet, gluten- and casein-free diet, and ketogenic diet) were excluded from the study. The anthropometric measurements were taken by well-trained researchers according to the measurement protocols. The height of the participants was measured in frankfort plane by a stadiometer having $0.1 \mathrm{~cm}$ sensitivity. The body weight was measured with a calibrated electronic scale having $0.1 \mathrm{~kg}$ sensitivity [28]. Attention was paid to being with a thin dress and without shoes for the body weight measurement. The Body Mass Index (BMI) was calculated as weight $(\mathrm{kg})$ divided by height squared $\left(\mathrm{m}^{2}\right)\left(\mathrm{BMl}=\right.$ weight/height $\left.{ }^{2}\right)$ and was classified according to the BMI cut-off points accepted by WHO [29]. In addition, WHO AnthroPlus software was used to evaluate age- and gender-specific BMI.

Daily energy intake and food consumption was assessed using $24 \mathrm{HR}$. So, the mothers were asked what their children consumed in the last 24 hours. To determine the amounts and portion size of the meals/foods "The Food and Meal Photo Catalog", a photographic atlas including Turkish foods and meals, was used [30]. Also, BEBIS, a food analysis software, was used to determine the dietary energy and nutrient intakes of the participants [31].

The BAMBI, 5-point Likert-type scale, was used to evaluate the meal behavior of the children. The scale, developed by Lukens and Lischeid [26] in order to determine the behavioral and nutritional problems of children with ASD, consists of 18 items and each item includes five different options indicating the frequency of occurrence ( 1 = never/rarely, $2=$ seldom, $3=$ occasionally, $4=$ often, $5=$ at almost every meal). In the Turkish validity and reliability study of the BAMBI, it was specified that the items 3, 9, 10 and 15 should be evaluated by reverse scoring [32]. The BAMBI gives three subscores (limited variety, food refusal and disruptive behavior) and a total score. The total point of the items $10,11,13,14,15,16,17$, and 18 refers to "limited variety" score (minimum 8, maximum 40 points). The total point of the items 1, 2, 4, 7, and 8 refers to "food refusal" score (minimum 5, maximum 25 points), and also the total point of the remaining items $(3,5,6,9$, and 12 ) refers to "disruptive behavior" score (minimum 5, maximum 25 points). Finally, the total point of all these subscores refers to the total BAMBI score (minimum 18, maximum 90 points). Higher BAMBI subscores and total score indicate more negative autism specific meal behaviors.

The ORTO-15, 4-point Likert-type scale, was used to evaluate the orthorexia tendency of the mothers. The scale, developed by Donini et al. [27], consists of 15 items and each item includes four different options indicating the frequency of occurence ( $1=$ always, $2=$ often, $3=$ sometimes, $4=$ never). The items $2,5,8$, and 9 are evaluated by reverse scoring. Also, the items 1 and 13 are evaluated by scoring as " $1=$ never, $2=$ always, $3=$ sometimes, and $4=$ often". The minimum and maximum scores are 15 and 60 points respectively, and also a score greater than or equal to 40 points refers to "high orthorexia tendency". 
Statistical analysis was performed using Statistical Package for Social Sciences (SPSS) version 22.0 [33]. Kolmogorov-Smirnov test was used to determine whether the data had normal distribution. The descriptive variables were expressed as "number (percentage)" or "mean \pm standard deviation" in Table 1. Mann Whitney $U$ test was used to evaluate the statistical differences between the groups (maternal education, maternal employment status, and ORTO-15 groups) in terms of quantitative variables (BAMBI scores, anthropometric measurements, and dietary intake). Spearman's rho correlation was used to evaluate the relationship between maternal features (maternal age at birth, breastfeeding duration, and ORTO-15 scores) and children's characteristics (BAMBI scores, anthropometric measurements, and dietary intake). Presence of diarrhea and abdominal pain in the children according to the maternal features were evaluated by Pearson's Chi-Square test. Boxplots were used to express the BAMBI scores of the mothers with high and low orthorexia tendency. Also, the quantitative variables (BAMBI scores, anthropometric measurements, and dietary intake) were expressed as "median (interquartile range)" in the comparison of the groups (maternal education and employment status). A p-value below 0.05 was considered statistically significant.

Table 1. General characteristics of children. Eskişehir, Turkey, 2016.

\begin{tabular}{|c|c|c|c|c|}
\hline \multirow{2}{*}{ Characteristics } & \multicolumn{4}{|c|}{$n=58$} \\
\hline & $n$ & $\%$ & $\bar{x}$ & SD \\
\hline \multicolumn{5}{|l|}{ Gender } \\
\hline Male & 47 & 81.0 & & \\
\hline Female & 11 & 19.0 & & \\
\hline Age (years) & & & 12.0 & 3.7 \\
\hline Male & & & 11.9 & 3.7 \\
\hline Female & & & 12.3 & 4.1 \\
\hline Age at diagnosis (years) & & & 3.1 & 1.3 \\
\hline Height $(\mathrm{cm})$ & & & 149.0 & 18.9 \\
\hline Male & & & 150.5 & 19.1 \\
\hline Female & & & 142.6 & 17.2 \\
\hline Weight (kg) & & & 50.8 & 23.2 \\
\hline Male & & & 51.1 & 24.1 \\
\hline Female & & & 49.6 & 19.9 \\
\hline BMI $\left(\mathrm{kg} / \mathrm{m}^{2}\right)$ & & & 21.8 & 6.1 \\
\hline School age (6-12 years) & & & 20.2 & 6.3 \\
\hline Adolescence (over 12 years) & & & 23.6 & 5.5 \\
\hline BMI Z-score & & & 0.86 & 2.04 \\
\hline BAMBI (total) & & & 41.1 & 8.6 \\
\hline BAMBI (limited variety) & & & 22.0 & 5.6 \\
\hline BAMBI (food refusal) & & & 8.5 & 3.7 \\
\hline BAMBI (disruptive behavior) & & & 10.8 & 2.7 \\
\hline \multicolumn{5}{|l|}{ Maternal characteristics } \\
\hline Maternal age at birth (years) & & & 28.3 & 6.4 \\
\hline \multicolumn{5}{|l|}{ Education } \\
\hline$<$ High school graduates & 26 & 44.8 & & \\
\hline ZHigh school graduates & 32 & 55.2 & & \\
\hline \multicolumn{5}{|l|}{ Employment status } \\
\hline Employed & 11 & 19.0 & & \\
\hline Unemployed & 47 & 81.0 & & \\
\hline Breastfeeding duration (months) & & & 12.6 & 9.5 \\
\hline ORTO-15 & & & 37.9 & 3.4 \\
\hline High orthorexia tendency $(\geq 40)$ & 21 & 36.2 & & \\
\hline Low orthorexia tendency $(<40)$ & 37 & 63.8 & & \\
\hline
\end{tabular}

Note: $\bar{x}$ : Mean; BAMBI: Brief Autism Mealtime Behavior Inventory; BMI: Body Mass Index; SD: Standard Deviation. 


\section{R E S U L T S}

Descriptive characteristics of participants are given in Table 1. The majority of the samples were male with the percentage of $81.0 \%$. The mean age was $11.9 \pm 3.7$ years and also ASD diagnosis age was $3.1 \pm 1.3$ years. The mean body weight, height, BMI, and BMI Z-score values were $50.8 \pm 23.3 \mathrm{~kg}$, $149.0 \pm 18.9 \mathrm{~cm}, 21.8 \pm 6.1 \mathrm{~kg} / \mathrm{m}^{2}$, and $0.86 \pm 2.04$, respectively. Also, the mean BAMBI scores of the samples were $41.1 \pm 8.6$ (total), $22.0 \pm 5.6$ (limited variety), $8.5 \pm 3.7$ (food refusal), and 10.8 \pm 2.7 (disruptive behavior), respectively. The mothers were asked for age of birth, breastfeeding duration, educational level, and employment status. The mean age of birth and breastfeeding duration were determined as $28.3 \pm 6.4$ years and $12.6 \pm 9.5$ months, respectively. Besides, $44.8 \%$ of mothers had low educational level (<high school graduates) and $81.0 \%$ of them were unemployed. The mean ORTO-15 score of the mothers was $37.9 \pm 3.4$ and it was found that $36.2 \%$ of the mothers had high orthorexia tendency.

The mean dietary energy, protein, carbohydrate, fat, dietary fiber, vitamin B6, magnesium and iron intakes were $1685.7 \pm 601.9 \mathrm{kcal}, 57.8 \pm 26.4 \mathrm{~g}, 209.0 \pm 82.1 \mathrm{~g}, 67.4 \pm 26.3 \mathrm{~g}, 21.0 \pm 7.8 \mathrm{~g}$, $1.2 \pm 0.5 \mathrm{mg}, 233.2 \pm 102.0 \mathrm{mg}$, and $9.9 \pm 4.0 \mathrm{mg}$, respectively. In addition, as expected, dietary intakes of adolescents were found to be higher than school-age children (not shown in the tables).

The BAMBI scores of the children of mothers with low and high orthorexia tendency were given in Figure 1. There were no statistically significant differences between these two groups in terms of BAMBI total and subscores ( $p>0.05$ ).

There were also no statistically significant differences between the children of mothers with low educational level (<high school graduate) and the children of mothers with high educational level ( $\geq$ high school graduate) in terms of BAMBI scores, body weight, BMI, and BMI-Z values ( $p>0.05$ ). The BMI values of the children were evaluated separately for school-age children and adolescents according to the mothers' employment status and educational level, and there were no statistically significant differences between the groups. On the other hand, in relation to dietary intake, the children of mothers with high educational level had significantly higher vitamin B6 intake $(p<0.05)$. However, the differences between two groups were not statistically significant in terms of dietary intake other than vitamin B6 ( $p>0.05)$. Also, when two age groups (school age and adolescence) were examined separately in terms of all nutrient intakes, there were no statistically significant differences between the mother groups (not shown in the tables) ( $p>0.05$ ). The BAMBI (limited variety) scores of the employed mothers' children were significantly higher than the scores of unemployed mothers' children $(p<0.05)$. In addition, there were no statistically significant differences between employed and unemployed mothers' children in terms of the other BAMBI scores (food refusal, disruptive behavior, and total) ( $p>0.05$ ) (Table 2).

Table 3 shows the correlations between maternal features (maternal age at birth, breastfeeding duration and ORTO-15 scores) and children's features (BAMBI total and subscores, body weight meusurements, BMI values, and dietary intakes). Maternal age at birth was negatively correlated with dietary energy and protein intakes $(p<0.05)$. Also, there were significantly positive correlations between breastfeeding duration and BAMBI scores (disruptive behavior and total) $(p<0.05)$. However, the ORTO-15 scores of mothers were not significantly correlated with children's features $(p>0.05)$.

The Gl symptoms of children (diarrhea and abdominal pain) are given in Table 4 . When the children were grouped according to the maternal features, there were no statistically significant 


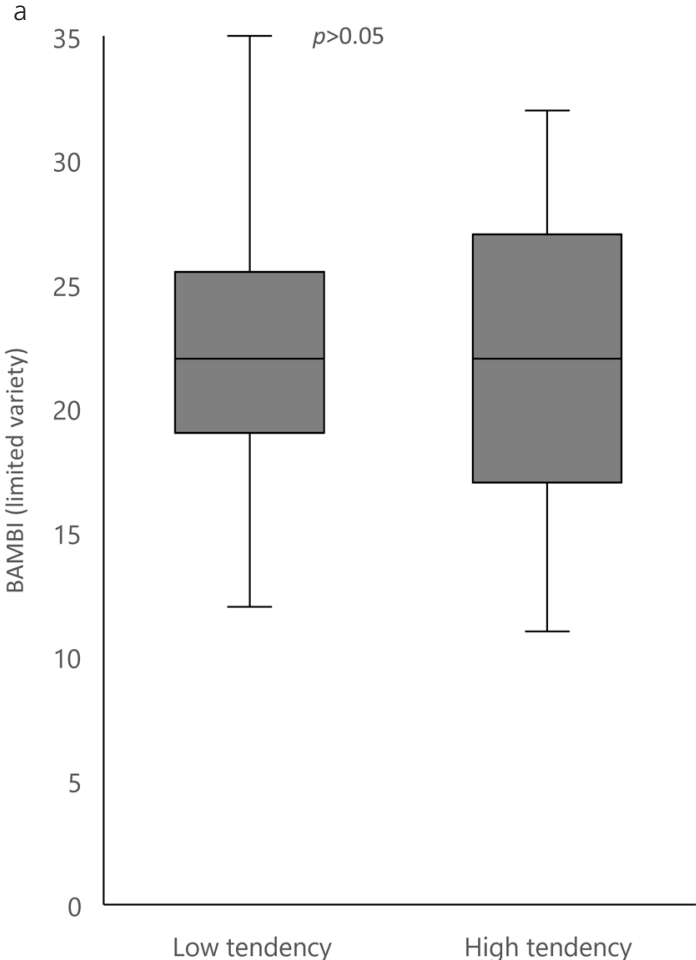

Orthorexia nervosa

C

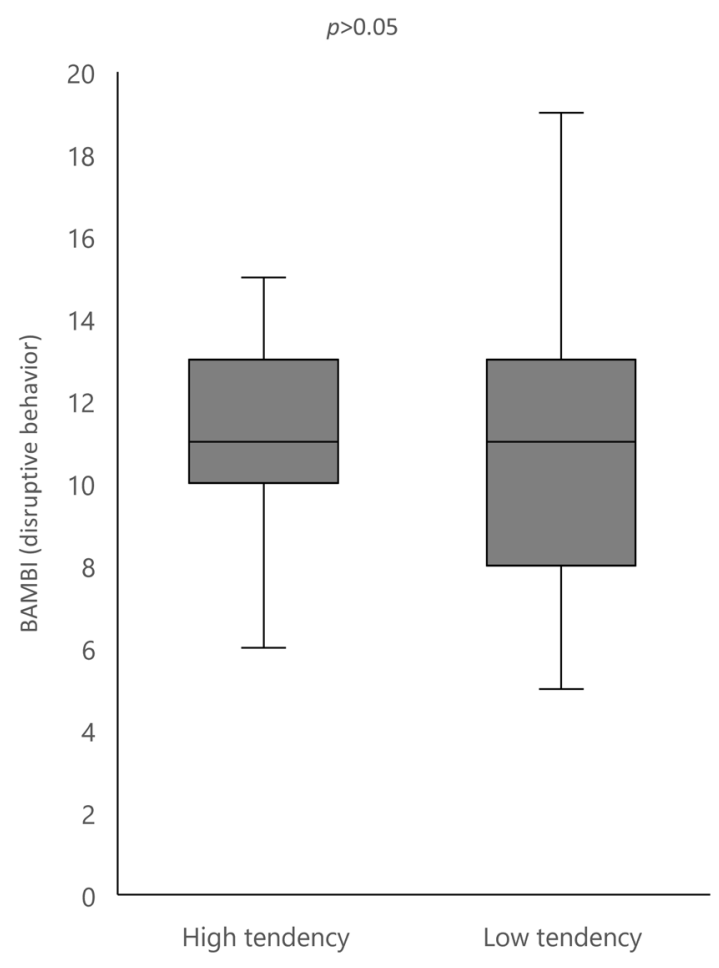

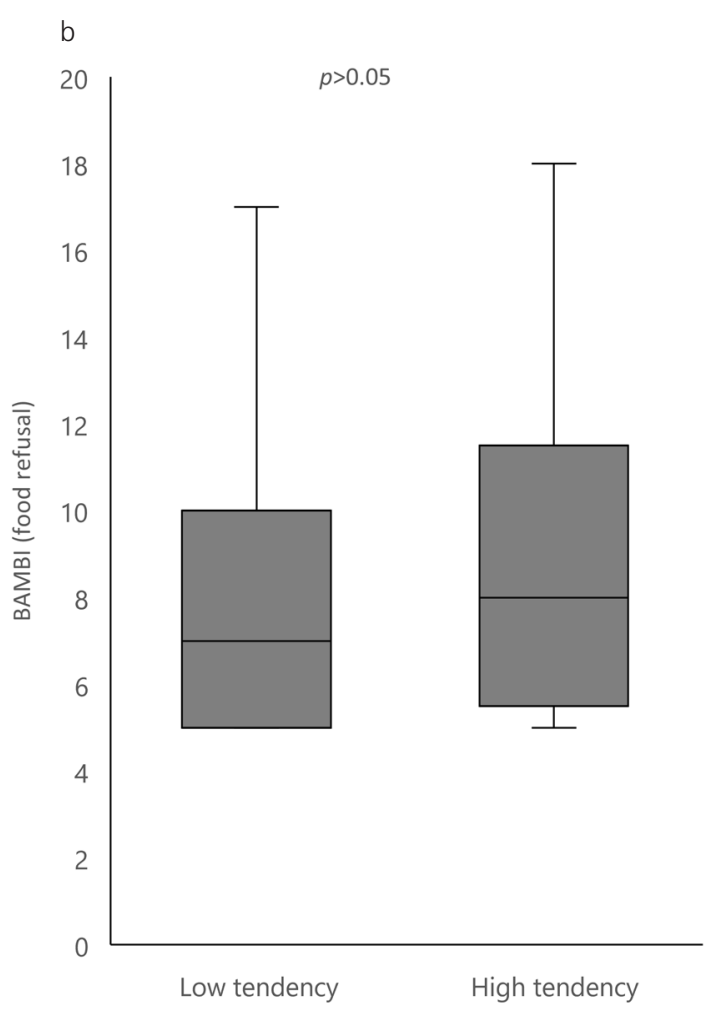

Orthorexia nervosa

d

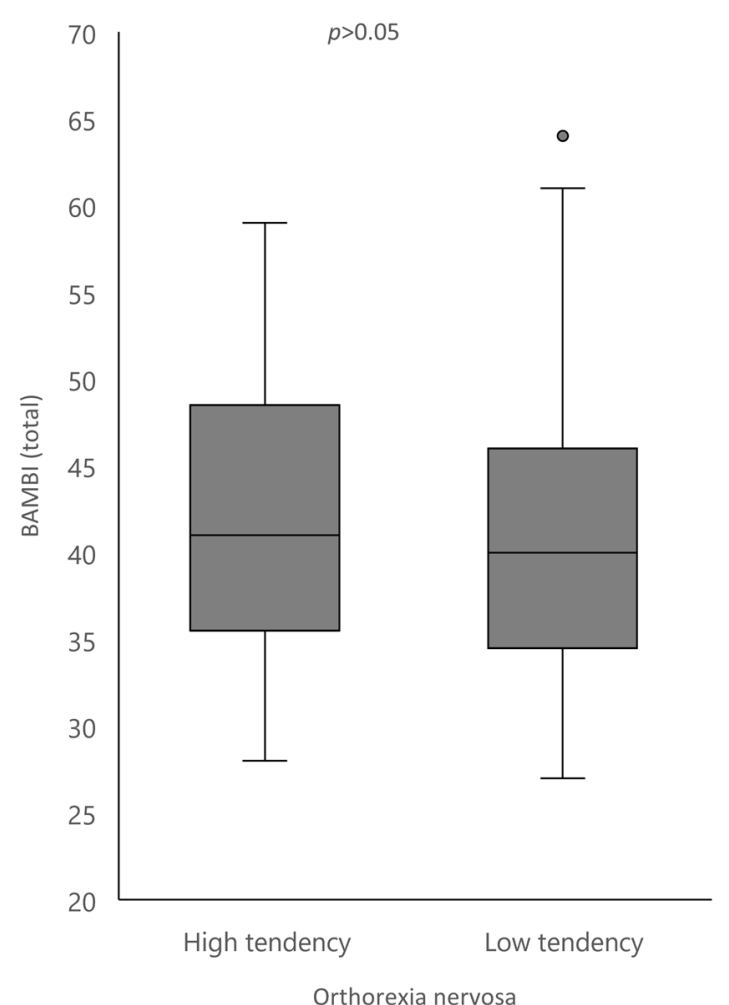

Figure 1. ORTO-15 in its two outcomes, respectively, reffering to the Briet Autısm Mealtime Behavior Inventory (BAMBI) Note: (a) limited variety, (b) food refusal, (c) disruptive behavior and (d) total. 
Table 2. BAMBI scores, anthropometric measurements and dietary intake of children according to maternal education and employment status. Eskişehir, Turkey, 2016.

\begin{tabular}{|c|c|c|c|c|c|c|}
\hline & \multicolumn{4}{|c|}{ Maternal education } & \multirow{3}{*}{ Z } & \multirow{3}{*}{$p$-value } \\
\hline & \multicolumn{2}{|c|}{$<$ High school graduates } & \multicolumn{2}{|c|}{$\geq$ High school graduates } & & \\
\hline & Median & Interquartile range & Median & Interquartile range & & \\
\hline \multicolumn{7}{|l|}{ BAMBI } \\
\hline BAMBI (limited variety) & 21.00 & 8.00 & 22.50 & 9.00 & -0.603 & 0.547 \\
\hline BAMBI (food refusal) & 7.50 & 6.00 & 8.00 & 6.00 & -0.111 & 0.911 \\
\hline BAMBI (disruptive behavior) & 11.00 & 4.00 & 11.00 & 4.00 & -0.434 & 0.664 \\
\hline BAMBI (total) & 40.00 & 11.00 & 40.50 & 12.00 & -0.266 & 0.790 \\
\hline \multicolumn{7}{|l|}{ Anthropometric measurements } \\
\hline Weight (kg) & 49.50 & 37.80 & 47.60 & 32.70 & -0.336 & 0.737 \\
\hline BMI $\left(\mathrm{kg} / \mathrm{m}^{2}\right)$ & 21.30 & 9.10 & 21.80 & 11.70 & -0.172 & 0.863 \\
\hline BMI (school age) & 16.00 & 10.40 & 21.80 & 9.80 & -1.044 & 0.296 \\
\hline BMI (adolescense) & 21.70 & 9.10 & 22.10 & 9.80 & -0.151 & 0.880 \\
\hline BMI Z-score & 0.97 & 2.70 & 1.72 & 3.31 & -1.188 & 0.235 \\
\hline \multicolumn{7}{|l|}{ Dietary intake } \\
\hline Energy (kcal) & 1445.60 & 872.10 & 1750.40 & 780.70 & -0.750 & 0.453 \\
\hline Protein (g) & 53.40 & 19.70 & 58.20 & 42.10 & -0.860 & 0.390 \\
\hline Protein (\%) & 13.00 & 4.00 & 13.00 & 4.50 & -0.378 & 0.705 \\
\hline Carbohydrate (g) & 189.60 & 148.80 & 188.40 & 132.80 & -0.313 & 0.755 \\
\hline Carbohydrate (\%) & 49.00 & 8.30 & 50.00 & 13.00 & -0.266 & 0.790 \\
\hline Fat (g) & 56.10 & 40.40 & 72.10 & 39.30 & -1.157 & 0.247 \\
\hline Fat (\%) & 37.00 & 7.00 & 36.00 & 10.00 & -0.008 & 0.994 \\
\hline Dietary fiber (g) & 20.40 & 12.10 & 21.50 & 12.00 & -0.977 & 0.328 \\
\hline Vitamin B6 (mg) & 1.01 & 0.56 & 1.26 & 0.61 & -2.408 & $0.016^{*}$ \\
\hline Magnesium (mg) & 196.10 & 118.60 & 241.00 & 129.50 & -1.673 & 0.094 \\
\hline \multirow[t]{4}{*}{ Iron (mg) } & 8.70 & 5.30 & 10.20 & 4.40 & -1.454 & 0.146 \\
\hline & \multicolumn{5}{|c|}{ Maternal employment status } & \\
\hline & \multicolumn{2}{|r|}{ Employed } & \multicolumn{2}{|c|}{ Unemployed } & \multirow{2}{*}{ Z } & \multirow{2}{*}{$p$-value } \\
\hline & Median & Interquartile range & Median & Interquartile range & & \\
\hline \multicolumn{7}{|l|}{ BAMBI } \\
\hline BAMBI (limited variety) & 25.00 & 6.00 & 21.00 & 8.00 & -2.563 & $0.010^{*}$ \\
\hline BAMBI (food refusal) & 8.00 & 4.00 & 7.00 & 6.00 & -0.767 & 0.443 \\
\hline BAMBI (disruptive behavior) & 11.00 & 5.00 & 11.00 & 4.00 & -0.320 & 0.749 \\
\hline BAMBI (total) & 45.00 & 6.00 & 39.00 & 12.00 & -1.857 & 0.063 \\
\hline \multicolumn{7}{|l|}{ Anthropometric measurements } \\
\hline Weight (kg) & 42.50 & 24.40 & 50.00 & 37.70 & -1.052 & 0.293 \\
\hline $\mathrm{BMI}\left(\mathrm{kg} / \mathrm{m}^{2}\right)$ & 21.20 & 8.30 & 21.70 & 11.10 & -0.307 & 0.759 \\
\hline BMI (school age) & 21.20 & 6.60 & 20.60 & 10.70 & -0.331 & 0.741 \\
\hline BMI (adolescense) & 24.40 & 10.20 & 21.70 & 9.20 & -0.205 & 0.838 \\
\hline BMI Z-score & 1.43 & 1.97 & 1.08 & 3.13 & -0.526 & 0.599 \\
\hline \multicolumn{7}{|l|}{ Dietary intake } \\
\hline Energy (kcal) & 1742.30 & 797.90 & 1735.20 & 801.30 & -0.248 & 0.804 \\
\hline Protein (g) & 50.80 & 24.90 & 56.90 & 33.70 & -0.129 & 0.897 \\
\hline Protein (\%) & 13.00 & 7.00 & 13.00 & 4.00 & -0.180 & 0.857 \\
\hline Carbohydrate (g) & 190.50 & 119.50 & 189.20 & 140.90 & -0.069 & 0.945 \\
\hline Carbohydrate (\%) & 50.00 & 18.00 & 49.00 & 10.00 & -0.238 & 0.812 \\
\hline Fat (g) & 68.50 & 52.80 & 61.40 & 37.80 & -0.248 & 0.804 \\
\hline Fat (\%) & 33.00 & 10.00 & 37.00 & 10.00 & -0.616 & 0.538 \\
\hline Dietary fiber (g) & 18.10 & 9.30 & 21.70 & 11.70 & -0.040 & 0.968 \\
\hline Vitamin B6 (mg) & 1.18 & 0.25 & 1.17 & 0.81 & -0.119 & 0.905 \\
\hline Magnesium (mg) & 233.30 & 119.90 & 215.50 & 105.80 & -0.407 & 0.684 \\
\hline Iron (mg) & 10.20 & 3.90 & 9.80 & 4.50 & -0.179 & 0.858 \\
\hline
\end{tabular}

Note: Mann Whitney U test: " $p<0.05$. BAMBI: Brief Autism Mealtime Behavior Inventory; BMI: Body Mass Index. 
Table 3. Correlation between maternal characteristics and nutrition-related characteristics of the children. Eskişehir, Turkey, 2016.

\begin{tabular}{|c|c|c|c|c|c|c|}
\hline & \multicolumn{2}{|c|}{ Maternal age at birth } & \multicolumn{2}{|c|}{ Breastfeeding duration } & \multicolumn{2}{|c|}{ ORTO-15 } \\
\hline & $r$ & $p$-value & r & $p$-value & r & $p$-value \\
\hline \multicolumn{7}{|l|}{ BAMBI } \\
\hline BAMBI (limited variety) & 0.023 & 0.865 & 0.220 & 0.106 & -0.047 & 0.728 \\
\hline BAMBI (food refusal) & -0.128 & 0.338 & 0.266 & 0.050 & 0.106 & 0.428 \\
\hline BAMBI (disruptive behavior) & 0.112 & 0.401 & 0.297 & $0.028^{*}$ & 0.052 & 0.700 \\
\hline BAMBI (total) & -0.028 & 0.835 & 0.270 & $0.046^{*}$ & 0.035 & 0.793 \\
\hline \multicolumn{7}{|l|}{ Anthropometric measurements } \\
\hline Weight & -0.065 & 0.627 & -0.191 & 0.161 & 0.105 & 0.432 \\
\hline BMI & -0.056 & 0.678 & -0.113 & 0.410 & 0.116 & 0.384 \\
\hline \multicolumn{7}{|l|}{ Dietary intake } \\
\hline Energy & -0.268 & $0.042^{*}$ & -0.083 & 0.548 & -0.130 & 0.332 \\
\hline Protein & -0.368 & $0.004^{*}$ & -0.118 & 0.389 & -0.132 & 0.323 \\
\hline Protein (\%) & -0.174 & 0.191 & -0.005 & 0.973 & -0.001 & 0.993 \\
\hline Carbohydrate & -0.252 & 0.056 & -0.042 & 0.762 & -0.134 & 0.318 \\
\hline Carbohydrate (\%) & -0.039 & 0.769 & 0.025 & 0.855 & 0.011 & 0.936 \\
\hline Fat & -0.162 & 0.223 & -0.158 & 0.249 & -0.074 & 0.583 \\
\hline Fat (\%) & 0.186 & 0.162 & 0.016 & 0.910 & 0.053 & 0.691 \\
\hline Dietary fiber & -0.078 & 0.559 & -0.076 & 0.582 & -0.081 & 0.548 \\
\hline Vitamin B6 & -0.257 & 0.051 & -0.095 & 0.489 & -0.234 & 0.077 \\
\hline Magnesium & -0.249 & 0.060 & -0.112 & 0.414 & -0.147 & 0.271 \\
\hline Iron & -0.246 & 0.063 & -0.106 & 0.442 & -0.171 & 0.200 \\
\hline
\end{tabular}

Note: Spearman's Rho correlation: " $p<0.05$; BAMBI: Brief Autism Mealtime Behavior Inventory; BMI: Body Mass Index.

Table 4. Presence of gastrointestinal symptoms at least once a month according to maternal characteristics. Eskişehir, Turkey, 2016.

\begin{tabular}{|c|c|c|c|c|c|c|c|c|c|c|c|c|}
\hline \multirow{3}{*}{ Maternal characteristics } & \multicolumn{6}{|c|}{ Diarrhea } & \multicolumn{6}{|c|}{ Abdominal pain } \\
\hline & \multicolumn{2}{|c|}{ Yes } & \multicolumn{2}{|c|}{ No } & \multirow{2}{*}{$\chi^{2}$} & \multirow{2}{*}{$p$-value } & \multicolumn{2}{|c|}{ Yes } & \multicolumn{2}{|c|}{ No } & \multirow{2}{*}{$\chi^{2}$} & \multirow{2}{*}{$p$-value } \\
\hline & $\mathrm{n}$ & $\%$ & $\mathrm{n}$ & $\%$ & & & $\mathrm{n}$ & $\%$ & $\mathrm{n}$ & $\%$ & & \\
\hline \multicolumn{13}{|l|}{ Maternal education } \\
\hline$<$ High school graduates & 9 & 34.6 & 17 & 65.4 & \multirow{2}{*}{0.220} & \multirow{2}{*}{0.639} & 4 & 15.4 & 22 & 84.6 & \multirow{2}{*}{2.698} & \multirow{2}{*}{0.100} \\
\hline$\geq$ High school graduates & 13 & 40.6 & 19 & 59.4 & & & 11 & 34.4 & 21 & 65.6 & & \\
\hline \multicolumn{13}{|l|}{ Maternal employment status } \\
\hline Employed & 6 & 54.5 & 5 & 45.5 & \multirow{2}{*}{1.592} & \multirow{2}{*}{0.207} & 6 & 54.5 & 5 & 45.5 & \multirow{2}{*}{5.825} & \multirow{2}{*}{$0.016^{*}$} \\
\hline Unemployed & 16 & 34.0 & 31 & 66.0 & & & 9 & 19.1 & 38 & 80.9 & & \\
\hline \multicolumn{13}{|l|}{ Maternal orthorexia tendency } \\
\hline High orthorexia tendency & 8 & 38.1 & 13 & 61.9 & \multirow{2}{*}{0.000} & \multirow{2}{*}{0.985} & 7 & 33.3 & 14 & 66.7 & \multirow{2}{*}{0.958} & \multirow{2}{*}{0.328} \\
\hline Low orthorexia tendency & 14 & 37.8 & 23 & 62.2 & & & 8 & 21.6 & 29 & 78.4 & & \\
\hline
\end{tabular}

Note: Pearson's Chi-square test: ${ }^{*} p<0.05$.

differences between the groups in terms of diarrhea presence $(p>0.05)$. In addition, the mothers were asked if the children had abdominal pain often. It was determined that the percentage of abdominal pain in employed mothers' children was $54.5 \%$ and this percentage was $19.1 \%$ in unemployed mothers' children $(p<0.05)$.

\section{DISCUSSION}

In many studies, it was reported that there is a close relationship between eating habits, nutritional status and ASD. The studies focused on maternal nutrition as much as the nutritional status 
of the children with ASD [34-37]. Mostly, the nutritional status of mothers during pregnancy was emphasized in the studies investigating the effect of maternal nutrition on autism [35-37]. However, there are no studies investigating the effect of maternal eating disorder on the meal behavior of children with ASD in the literature.

In this study, the mean age of children with ASD, $81.0 \%$ of whom were male, was $12.0 \pm 3.7$ years. Also, the mean heights were $150.5 \pm 19.1 \mathrm{~cm}$ and $142.6 \pm 17.2 \mathrm{~cm}$ in males and females, respectively. In Turkey Dietary Guideline (TUBER), the specified median height values were $149 \mathrm{~cm}$ and $151 \mathrm{~cm}$ for 12 -year-old males and females, respectively [38]. On the other hand, the mean body weight of males and females $(51.1 \pm 24.1 \mathrm{~kg}$ and $49.6 \pm 19.9 \mathrm{~kg}$ respectively) was found to be higher than the median body weight values for 12 -year-old children specified in TUBER (38.9kg for males and $41.2 \mathrm{~kg}$ for females). In addition, it was determined that the daily dietary protein, carbohydrate and fiber intakes of children were higher than the adequate intake levels of protein $(43.8 \mathrm{~g}$ for males and $45.8 \mathrm{~g}$ for females), carbohydrate (130g) and fiber (19g) specified in TUBER. Based on all these results, it is thought that the children with ASD do not have serious physical development retardation.

The BAMBI is a standardized assessment tool developed to evaluate meal behavior problems in children with ASD. In our study, the mean total BAMBI score was 41.1 \pm 8 .6. Since there was not a control group in the study, children with ASD were not comparable with typically developing children in terms of BAMBI scores. However, in a study conducted by Zobel-Lachiusa et al. [39], the mean total $B A M B I$ score in children with ASD was found to be 44.39 \pm 10.83 ; on the other hand, this mean value was 30.08 \pm 7.90 in typically developing children $(p<0.05)$. Because of BAMBI do not have cut-off points, the children with ASD could not been grouped in terms of meal behavior. Even so the BAMBI scores show that the children with ASD have more obvious meal behavior problems than typically developing children.

Studies conducted with mentally healthy children and their mothers show that maternal eating disorders and nutritional status may reflect the eating habits and nutritional status of children [40-42]. In this study, the fact that there was no statistically significant difference between the children of mothers with low and high orthorexia tendency in terms of BAMBI scores indicates that the mother's orthorexia tendency was not influential on meal behavior in children with ASD. Therefore, it can be considered maternal eating disorders do not significantly affect meal behaviors of children with ASD.

Many studies reported that mother's empowerment and autonomy based on educational and socioeconomic status have a direct positive effect on healthy eating habits and anthropometric indicators in children [43-48]. In a study, it was reported that the children whose mothers had salary from employment had a better Weight for Age Z score (WAZ) and Weight for Height Z score (WHZ), and it was also reported maternal educational status was correlated with $\mathrm{WHZ}$ of children $(r=0.25$ $p=0.001$ ) [12]. In this study, it was found that dietary energy, protein, fat, fiber, vitamin B6, iron and magnesium intakes were higher in autistic children of mothers with high educational level. However, there was a statistically significant difference between the groups only in terms of vitamin B6 intake. Likewise, mother's educational level does not have an effect on meal behavior and anthropometric measurements of children with ASD. It is thought that maternal demographic factors have a limited effect on the nutritional status in children with ASD.

In previous studies, advanced maternal age was found to be associated with increased risk of ASD [49]. According to the results of the 6- and 66-month Taiwan Birth Cohort Study, the risk 
of being diagnosed with ASD was increased by the maternal age being over 40 years old [50]. Also, Rubenstein et al. [51] reported that advanced maternal age is a risk factor for ASD, but it was not independently associated likely, because it is a consequence of maternal education and other sociodemographic features. Unlike, the mean maternal age at birth was not very high $(28.3 \pm 6.4$ years) in our study. This may be because the sample size in this study is relatively small compared to the other studies. Furthermore, maternal age was significantly associated with daily dietary energy and protein intake in children with ASD. In the literature, no data was found on the relationship between maternal age and nutritional status of children with ASD. However, in a study conducted with typically developing children and their mothers, advanced maternal age was reported to be associated with malnutrition in children [52].

There is convincing evidence that breastfeeding has positive effects on ASD [53,54]. In a meta-analysis including the results of seven studies, it was reported that the children with ASD were significantly less likely to have been breastfed than typically developing children (Odds Ratio $(O R)=0.61$, $\% 95$ Confidence Interval $(\mathrm{Cl})=0.45-0.83, p=0.002)$, therefore breastfeeding could provide protection against ASD [53]. In a case-control study evaluating the association between breastfeeding and ASD, the absence of breastfeeding when compared to breastfeeding for more than six months was associated with a significant increase in the risk of ASD ( $O R=2.48, \% 95 \mathrm{Cl}=1.42-4.35)$ [54]. Besides, in a study by Soke et al. [55], the reported mean breastfeeding duration of the children with ASD was 7.3 \pm 7.2 months and that of control children was 9.3 \pm 7.2 months. In another study, Boucher et al. [56] reported that the mean breastfeeding duration in the children with ASD was 6.9 9.1 months. It is well-known that breastfeeding is a traditional behavior in Turkish society. So, it is nearly impossible to report that the higher breastfeeding durations in our study $(12.6 \pm 9.5$ months) is associated with ASD.

Comorbidities often accompany ASD, and Gl dysfunction is among the most frequently cited comorbidities $[57,58]$. The prevalence of $\mathrm{Gl}$ dysfunction in the children with ASD range from 9 to $70 \%$ [59-63]. A meta-analysis reported that the children with ASD experienced GI symptoms such as diarrhea $(\mathrm{OR}=3.63 ; 95 \% \mathrm{Cl}=1.82-7.23)$ and abdominal pain $(\mathrm{OR}=2.45 ; 95 \% \mathrm{Cl}=1.19-5.07)$ significantly more than control children [64]. In another study, the percentages of children with ASD who experienced diarrhea and abdominal pain in the last three months were $13 \%$ and $5.1 \%$, respectively. This rate was $1.6 \%$ for both symptoms in typically developing children [65]. In this study, the percentages of the children who experienced diarrhea and abdominal pain at least once a month were $37.9 \%$ and $25.9 \%$, respectively. In addition, maternal features were not found to be effective on Gl symptoms in the children with ASD. It is thought that, Gl symptoms were more frequent in this study, because all of the children had severe autism characterized by highly visible lack of communication skills, very limited social interactions, and extreme difficulty coping with unexpected changes.

Orthorexia tendency of the mothers was not associated with meal behavior, anthropometric measurements and dietary intake of the children with ASD in our study. The ORTO-15, developed by Donini et al. [27] based on the Bratman's test, was used to determine the orthorexia tendency of mothers. Varga et al. [66] reported that the validity of orthorexia assessment instruments, including ORTO-15, was not convincing. Because the Bratman's test includes items that are not unique to orthorexia [67]. It is also based on clinical experience and its validity has never been checked. The limitations of the Bratman's test are making the face-validity of the ORTO-15 doubtful. So, further studies are needed to clarify the appropriate diagnostic methods for orthorexia. 


\section{CONCLUSION}

Within the scope of the study, we examined the effects of some maternal features including the maternal age at birth, educational level, employment status, breastfeeding duration, and orthorexia tendency on meal behaviors, dietary intakes, anthropometric measurements and some Gl symptoms in children with ASD. We concluded that maternal features are not associated with children's meal behavior in this sample. However, it may be mentioned that the maternal age and educational level have a very limited effect on the dietary intake in children with ASD. More comprehensive longitudinal studies with large sample sizes are needed to investigate if maternal eating disorders and demographic factors were associated with meal behavior and nutritional status in autistic children.

\section{ACKNOWLEDGMENTS}

We are thankful to Birsen YIlmaz for contributing to the editing of the article.

\section{CONTRIBUTORS}

N ATEŞ-ŞAHINKAYA designed the study, coordinated the data collection, and contributed interpretation of the article. N ACAR-TEK designed and coordinated the study, contributed interpretation and drafting of the article, and also approved the final version of the article. E ADIGÜZEL contributed statistical analysis, interpretation and drafting of the article.

\section{REFERENCES}

1. American Psychiatric Association. Diagnostic and statistical manual of mental disorders: DSM-5. Arlington: American Psychiatric Publishing; 2013.

2. Miodovnik A, Harstad E, Sideridis G, Huntington N. Timing of the diagnosis of attention-deficit/hyperactivity disorder and autism spectrum disorder. Am Acad Pediatrics. 2015;136(4):830-7. https://doi.org/10.1542/ peds.2015-1502

3. Zwaigenbaum L, Bauman ML, Fein D, Pierce $K$, Buie T, Davis $P A$, et al. Early screening of autism spectrum disorder: recommendations for practice and research. Am Acad Pediatrics. 2015;136(Suppl1):41-59. https:// doi.org/10.1542/peds.2014-3667D

4. American Psychiatric Association. Diagnostic and statistical manual of mental disorders: DSM-4-TR. Washington: American Psychiatric Publishing; 2000.

5. Baio J, Wiggins L, Christensen DL, Maenner MJ, Daniels J, Warren Z, et al. Prevalence of autism spectrum disorder among children aged 8 years: autism and developmental disabilities monitoring network, 11 Sites, United States, 2014. Morb Mortal Wkly Rep. 2018;67(6):1-23. https://doi.org/10.15585/mmwr.ss6706a1

6. Bjørklund $G$, Chartrand $M$. Nutritional and environmental influences on autism spectrum disorder. J Nutr Disorders Ther. 2016;6(1):e123. https://doi.org/10.4172/2161-0509.1000e123

7. Endreffy I, Bjørklund G, Dicső F, Urbina MA, Endreffy E. Acid glycosaminoglycan (aGAG) excretion is increased in children with autism spectrum disorder, and it can be controlled by diet. Metab Brain Dis. 2016;31(2):273-8. https://doi.org/10.1007/s11011-015-9745-2

8. Mandy W, Lai MC. Annual research review: the role of the environment in the developmental psychopathology of autism spectrum condition. J Child Psychol Psychiatry. 2016;57(3):271-92. https://doi.org/10.1111/ jcpp. 12501

9. Ranjan S, Nasser JA. Nutritional status of individuals with autism spectrum disorders: do we know enough? Adv Nutr. 2015;6(4):397-407. https://doi.org/10.3945/an.114.007914 
10. DeMand A, Johnson C, Foldes E. Psychometric properties of the brief autism mealtime behaviors inventory. J Autism Dev Disord. 2015;45(9):2667-73. https://doi.org/10.1007/s10803-015-2435-47

11. Meguid NA, Anwar M, Bjørklund G, Hashish A, Chirumbolo S, Hemimi M, et al. Dietary adequacy of Egyptian children with autism spectrum disorder compared to healthy developing children. Metab Brain Dis. 2017;32(2):607-15. https://doi.org/10.1007/s11011-016-9948-1

12. Natale RA, Messiah SE, Asfour L, Uhlhorn SB, Delamater A, Arheart KL. Role modeling as an early childhood obesity prevention strategy: effect of parents and teachers on preschool children's healthy lifestyle habits. J Dev Behav Pediatr. 2014;35(6):378-87. https://doi.org/10.1097/DBP.0000000000000074

13. Larsen JK, Hermans RC, Sleddens EF, Engels RC, Fisher JO, Kremers SP. How parental dietary behavior and food parenting practices affect children's dietary behavior. Interacting sources of influence? Appetite. 2015;89:246-57. https://doi.org/10.1016/j.appet.2015.02.012

14. Negash C, Whiting SJ, Henry CJ, Belachew T, Hailemariam TG. Association between maternal and child nutritional status in Hula, rural Southern Ethiopia: a cross sectional study. Plos One. 2015;10(11):e0142301. https://doi.org/10.1371/journal.pone.0142301

15. Scaglioni S, De Cosmi V, Ciappolino V, Parazzini F, Brambilla P, Agostoni C. Factors influencing children's eating behaviours. Nutrients. 2018;10(6):706. https://doi.org/10.3390/nu10060706

16. Alderman H, Headey DD. How important is parental education for child nutrition? World Dev. 2017;94:448-64. https://doi.org/10.1016/j.worlddev.2017.02.007

17. Di Cesare M, Bhatti Z, Soofi SB, Fortunato L, Ezzati M, Bhutta ZA. Geographical and socioeconomic inequalities in women and children's nutritional status in Pakistan in 2011: an analysis of data from a nationally representative survey. Lancet Glob Health. 2015;3(4):229-39. https://doi.org/10.1016/S2214-10 9X(15)70001-X

18. Makoka D, Masibo PK. Is there a threshold level of maternal education sufficient to reduce child undernutrition? Evidence from Malawi, Tanzania and Zimbabwe. Bmc Pediatr. 2015;15(1):96. https://doi. org/10.1186/s12887-015-0406-8

19. Johri M, Subramanian SV, Koné GK, Dudeja S, Chandra D, Minoyan N, et al. Maternal health literacy is associated with early childhood nutritional status in India. J Nutr. 2016;146(7):1402-10. https://doi. org/10.3945/jn. 115.226290

20. Ickes SB, Hurst TE, Flax VL. Maternal literacy, facility birth, and education are positively associated with better infant and young child feeding practices and nutritional status among Ugandan children. J Nutr. 2015;145(11):2578-86. https://doi.org/10.3945/jn.115.214346

21. Eshete H, Abebe Y, Loha E, Gebru T, Tesheme T. Nutritional status and effect of maternal employment among children aged 6-59 months in Wolayta Sodo town, southern Ethiopia: a cross-sectional study. Ethiop J Health Sci. 2017;27(2):155-62. https://doi.org/10.4314/ejhs.v27i2.8

22. Huda TM, Hayes A, El Arifeen S, Dibley MJ. Social determinants of inequalities in child undernutrition in Bangladesh: a decomposition analysis. Mat Child Nutr. 2018;14(1):12440. https://doi.org/10.1111/mcn. 12440

23. Rogers LG, Magill-Evans J, Rempel GR. Mothers' challenges in feeding their children with autism spectrum disorder: managing more than just picky eating. J Dev Phys Disabil. 2012;24(1):19-33. https://doi.org/10.1007/ s10882-011-9252-2

24. Marí-Bauset S, Llopis-González A, Zazpe-García I, Marí-Sanchis A, Morales-Suárez-Varela M. Nutritional status of children with autism spectrum disorders (ASDs): a case-control study. J Autism Dev Disord. 2015;45(1):203-12. https://doi.org/10.1007/s10803-014-2205-8

25. World Health Organization. Recognizing adolescence. Geneva: Organization; 2014 [cited 2020 Mar 20]. Available from: https://apps.who.int/adolescent/second-decade/section2/page1/recognizing-adolescence.html

26. Lukens CT, Linscheid TR. Development and validation of an inventory to assess mealtime behavior problems in children with autism. J Autism Dev Disord. 2008;38(2):342-52. https://doi.org/10.1007/s10803-007-0401-5

27. Donini LM, Marsili D, Graziani MP, Imbriale M, Cannella C. Orthorexia nervosa: validation of a diagnosis questionnaire. Eat Weight Disord. 2005;10(2):28-32. https://doi.org/10.1007/BF03327537

28. Lohman T, Roche A, Martorell R. Anthropometric Standardization Reference Manual. Champaign: Human Kinetics Books; 1991. 
29. World Health Organization. Body mass index. Geneva: Organization; c2020 [cited 2019 Sep 29]. Available from: http://www.euro.who.int/en/health-topics/disease-prevention/nutrition/a-healthy-lifestyle/body-massindex-bmi

30. Rakıcıoğlu N, Acar-Tek N, Ayaz A, Pekcan G. Yemek ve besin fotoğraf kataloğu: ölçü ve miktarlar (Food and Meal Photo Catalog: Measurements and Quantities). Ankara: Ata Ofset; 2014.

31. Ebispro for Windows. Data Bases: Bundeslebenmittelschlüssell 11.3 and other sources. Turkish version BeBis [software]. Stuttgart: Ebispro; 2004.

32. Meral BF, Fidan A. A study on Turkish adaptation, validity and reliability of the brief autism mealtime behavior inventory (BAMBI). Procedia Soc Behav Sci. 2014;116:403-8. https://doi.org/10.1016/j.sbspro.2014.01.230

33. International Business Machines Corporation. Statistical Package for Social Sciences. version 22.0 [software]. Chicago: IBM; 2013.

34. Fujiwara T, Morisaki, N, Honda $Y$, Sampei $M$, Tani $Y$. Chemicals, nutrition, and autism spectrum disorder: a mini-review. Front Neurosci. 2016;10:174. https://doi.org/10.3389/fnins.2016.00174

35. Lyall K, Munger KL, O'Reilly ÉJ, Santangelo SL, Ascherio A. Maternal dietary fat intake in association with autism spectrum disorders. Am J Epidemiol. 2013;178(2):209-20. https://doi.org/10.1093/aje/kws433

36. Grant WB, Soles CM. Epidemiologic evidence for supporting the role of maternal vitamin D deficiency as a risk factor for the development of infantile autism. Dermatoendocrinol. 2009;1(4):223-8. https://doi. org/10.4161/derm.1.4.9500

37. Surén P, Roth C, Bresnahan M, Haugen M, Hornig M, Hirtz D, et al. Association between maternal use of folic acid supplements and risk of autism spectrum disorders in children. Jama. 2013;309(6):570-7. https:// doi:10.1001/jama.2012.155925

38. Ministry of Health (Turkey). Turkey Dietary Guideline-2015 (TUBER). Ankara: Ministry; 2016.

39. Zobel-Lachiusa J, Andrianopoulos MV, Mailloux Z, Cermak SA. Sensory differences and mealtime behavior in children with autism. Am J Occup Ther. 2015;69(5). https://doi.org/10.5014/ajot.2015.016790

40. Stein A, Woolley H, Cooper S, Winterbottom J, Fairburn CG, Cortina-Borja M. Eating habits and attitudes among 10-year-old children of mothers with eating disorders: longitudinal study. Br J Psychiatry. 2006;189(4):324-9. https://doi.org/10.1192/bjp.bp.105.014316

41. Cerniglia L, Cimino S, Tafà M, Marzilli E, Ballarotto G, Bracaglia F. Family profiles in eating disorders: family functioning and psychopathology. Psychol Res Behav Manag. 2017;10:305-12. https://doi.org/10.2147/ PRBM.S145463

42. Huicho L, Segura ER, Huayanay-Espinoza CA, Guzman JN, Restrepo-Méndez MC, Tam Y, et al. Child health and nutrition in Peru within an antipoverty political agenda: a Countdown to 2015 country case study. Lancet Glob Health. 2016;4(6):414-26. https://doi.org/10.1016/S2214-109X(16)00085-1

43. Emina JBO, Ngianga-Bakwin K, Inungu J, Yazoume YE. Maternal education and child nutritional status in the Democratic Republic of Congo. J Public Health Epidemiol. 2011;3(12):576-92. https://doi.org/10.5897/ JPHE11.130

44. Imai KS, Annim SK, Kulkarni VS, Gaiha R. Women's empowerment and prevalence of stunted and underweight children in rural India. World Dev. 2014;62:88-105. https://doi.org/10.1016/j.worlddev.2014.05.001

45. Cunningham K, Ploubidis GB, Menon P, Ruel M, Kadiyala S, Uauy R, et al. Women's empowerment in agriculture and child nutritional status in rural Nepal. Public Health Nutr. 2015;18(17):3134-45. https://doi. org/10.1017/S1368980015000683

46. Ahsan KZ, El Arifeen S, Al-Mamun MA, Khan SH, Chakraborty N. Effects of individual, household and community characteristics on child nutritional status in the slums of urban Bangladesh. Arch Public Health. 2017;75(1):9. https://doi.org/10.1186/s13690-017-0176-x

47. Cunningham K, Ruel M, Ferguson E, Uauy R. Women's empowerment and child nutritional status in South Asia: A synthesis of the literature. Matern Child Nutr. 2015;11(1):1-19. https://doi.org/10.1111/mcn.12125

48. Cunningham K, Headey D, Singh A, Karmacharya C, Rana PP. Maternal and child nutrition in Nepal: examining drivers of progress from the mid-1990s to 2010s. Glob Food Sec. 2017;13:30-7. https://doi.org/10.1016/j. gfs.2017.02.001

49. Croen LA, Najjar DV, Fireman B, Grether JK. Maternal and paternal age and risk of autism spectrum disorders. Arch Pediatr Adolesc Med. 2007;161(4):334-40. https://doi:10.1001/archpedi.161.4.334 
50. Lung FW, Chiang TL, Lin SJ, Lee MC, Shu BC. Advanced maternal age and maternal education disparity in children with autism spectrum disorder. Matern Child Health J. 2018;22(7):941-9. https://doi.org/10.1007/ s10995-018-2470-9

51. Rubenstein E, Durkin MS, Harrington RA, Kirby RS, Schieve LA, Daniels J. Relationship between advanced maternal Age and timing of first developmental evaluation in children with autism. J Dev Behav Pediatr. 2018;39(8):601-9. https://doi.org/10.1097/DBP.0000000000000601

52. Simon D, Adams AM, Madhavan S. Women's social power, child nutrition and poverty in Mali. J Biosoc Sci. 2002;34(2):193-213. https://doi.org/10.1017/S0021932002001931

53. Tseng PT, Chen YW, Stubbs B, Carvalho AF, Whiteley P, Tang CH, et al. Maternal breastfeeding and autism spectrum disorder in children: a systematic review and meta-analysis. Nutr Neurosci. 2019;22(5):354-62. https://doi.org/10.1080/1028415X.2017.1388598

54. Schultz ST, Klonoff-Cohen HS, Wingard DL, Akshoomoff NA, Macera CA, Ji M, et al. Breastfeeding, infant formula supplementation, and Autistic Disorder: the results of a parent survey. Int Breastfeed J. 2006;1(1):16. https://doi.org/10.1186/1746-4358-1-16

55. Soke GN, Maenner M, Windham G, Moody E, Kaczaniuk J, DiGuiseppi C, et al. Association between breastfeeding initiation and duration and autism spectrum disorder in preschool children enrolled in the study to explore early development. Autism Res. 2019;12:816-29. https://doi.org/10.1002/aur.2091

56. Boucher O, Julvez J, Guxens M, Arranz E, Ibarluzea J, Miguel MS, et al. Association between breastfeeding duration and cognitive development, autistic traits and ADHD symptoms: a multicenter study in Spain. Pediatr Res. 2017;81(3):434-42. https://doi:10.1038/pr.2016.238

57. Berry RC, Novak P, Withrow N, Schmidt B, Rarback S, Feucht S, et al. Nutrition management of gastrointestinal symptoms in children with autism spectrum disorder: guideline from an expert panel. J Acad Nutr Diet. 2015;115(12):1919-27. https://doi.org/10.1016/j.jand.2015.05.016

58. Kral TV, Eriksen WT, Souders MC, Pinto-Martin JA. Eating behaviors, diet quality, and gastrointestinal symptoms in children with autism spectrum disorders: a brief review. J Pediatr Nurs. 2013;28(6):548-56. https://doi.org/10.1016/j.pedn.2013.01.008

59. Black C, Kaye JA, Jick H. Relation of childhood gastrointestinal disorders to autism: nested case-control study using data from the UK General Practice Research Database. Br Med J. 2002;325:419-21. https://doi. org/10.1136/bmj.325.7361.419

60. Levy SE, Souders MC, Ittenbach RF, Giarelli E, Mulberg AE, Pinto-Martin JA. Relationship of dietary intake to gastrointestinal symptoms in children with autistic spectrum disorders. Biol Psychiatry. 2007;61(4):492-7. https://doi:10.1016/j.biopsych.2006.07.013

61. Molloy CA, Manning-Courtney P. Prevalence of chronic gastrointestinal symptoms in children with autism and autistic spectrum disorders. Autism. 2003;7(2):165-71. https://doi.org/10.1177/1362361303007002004

62. Nikolov RN, Bearss KE, Lettinga J, Erickson C, Rodowski M, Aman MG, et al. Gastrointestinal symptoms in a sample of children with pervasive developmental disorders. J Autism Dev Disord. 2009;39(3):405-13. https:// doi.org/10.1007/s10803-008-0637-8

63. Valicenti-McDermott M, McVicar K, Rapin I, Wershil BK, Cohen H, Shinnar S. Frequency of gastrointestinal symptoms in children with autistic spectrum disorders and association with family history of autoimmune disease. J Dev Behav Pediatr. 2006;27(2):128-36. https://doi.org/10.1097/00004703-200604002-00011

64. McElhanon BO, McCracken C, Karpen S, Sharp WG. Gastrointestinal symptoms in autism spectrum disorder: a meta-analysis. Pediatrics. 2014;133(5):872-83. https://doi.org/10.1542/peds.2013-3995

65. Chaidez V, Hansen RL, Hertz-Picciotto I. Gastrointestinal problems in children with autism, developmental delays or typical development. J Autism Dev Disord. 2014;44(5):1117-27. https://doi.org/10.1007/s10803013-1973-X

66. Varga M, Dukay-Szabó S, Túry F, van Furth EF. Evidence and gaps in the literature on orthorexia nervosa. Eat Weight Disord. 2013;18(2):103-11. https://doi.org/10.1007/s40519-013-0026-y

67. Bratman S. Original essay on orthorexia. Yoga J. 1997 [cited 2019 Sep 29]. Available from: http://www. orthorexia.com/index.php?page=essay 